\title{
Tissue Expression of Nephrin in Human and Pig
}

\author{
ARVI-MATTI KUUSNIEMI, MARJO KESTILÄ, JAAKKO PATRAKKA, \\ ANNE-TIINA LAHDENKARI, VESA RUOTSALAINEN, CHRISTER HOLMBERG, \\ RIITTA KARIKOSKI, RIITTA SALONEN, KARL TRYGGVASON, AND HANNU JALANKO
}

\author{
Hospital for Children and Adolescents and Biomedicum Helsinki [A.-M.K., J.P., A.-T.L., C.H., R.K., H.J.], \\ University of Helsinki, 00290 Helsinki, Finland; Department of Molecular Medicine [M.K.], National \\ Public Health Institute, 00290 Helsinki, Finland; Biocenter and Department of Biochemistry [V.R.], \\ University of Oulu, 90571 Oulu, Finland; Department of Obstetrics and Gynecology [R.S.], University of \\ Helsinki, 00290 Helsinki, Finland; and Division of Matrix Biology [J.P., K.T.], Department of Medical \\ Biochemistry and Biophysics, Karolinska Institute, 17177 Stockholm, Sweden
}

\begin{abstract}
ABST
Nephrin is a major component of the glomerular filtration
barrier. Mutations in the nephrin gene (NPHS1) are responsible
for congenital nephrotic syndrome of the Finnish type (NPHS1).
Nephrin was at first thought to be podocyte specific, but recent
studies have suggested that nephrin is also expressed in nonrenal
tissues such as pancreas and CNS. We studied the expression of
nephrin in human and porcine tissues at different stages of
development and correlated these findings to clinical character-
istics of NPHS1 children. Immunofluorescence staining and
Western blotting were used to detect nephrin protein in frozen
tissue samples. Polyclonal antibodies against the intracellular
part of nephrin were used in these analyses. In situ hybridization
was used to detect nephrin mRNA in specimens from normal
human subjects and patients with NPHS1. Nephrin protein was
not detected in nonrenal tissues obtained from human and por-
\end{abstract}
cine fetuses, newborns, and infants. Likewise, nephrin mRNA expression was not observed outside kidney glomerulus in normal or NPHS1 children. The phenotype analysis of NPHS1 children with severe nephrin gene mutations supported the findings in the tissue expression studies and revealed no impairment of the neurologic, testicular, or pancreatic function in a great majority of the patients. The studies suggest that nephrin has no major clinical significance outside the kidney. (Pediatr Res 55: 774-781, 2004)

Abbreviations
NPHS1, congenital nephrotic syndrome of the Finnish type
IF, immunofluorescence
RT-PCR, reverse transcriptase-PCR
EST, expressed sequence tag

Nephrin is a cell adhesion protein produced in kidney by the glomerular epithelial cells (1). It is located at the podocyte slit diaphragm, which is a crucial component of the glomerular filtration barrier (2-4). Nephrin has 1241 amino acid residues and belongs to the immunoglobulin superfamily containing eight immunoglobulin-like domains and one fibronectin-type domain in the extracellular part. The intracellular part has no homology with other known proteins. It contains tyrosine residues, and nephrin was recently shown to take part in cell signaling together with two other podocyte proteins, podocin and CD2-associated protein (5-10). The extracellular part of nephrin interacts with Neph1, and the two proteins probably form the backbone of the podocyte slit diaphragm (11-13).

Nephrin is encoded by NPHS1 gene located on chromosome $19 q 13.1$ (14). This gene consists of 29 exons and has a size of

Received May 12, 2003; accepted November 11, 2003.

Correspondence: Hannu Jalanko, M.D., Hospital for Children and Adolescents, University of Helsinki, 00290 Helsinki, Finland; e-mail: hannu.jalanko@hus.fi

DOI: 10.1203/01.PDR.0000117842.10241.2C
$26 \mathrm{~kb}$. Mutations in NPHS1 lead to congenital nephrotic syndrome of the Finnish type (NPHS1), which is an autosomal recessive disorder characterized by nephrotic syndrome soon after birth (15). The disease is highly enriched in the Finnish population, but cases of NPHS1 are found all over the world (16-18). The Finnish patients have two important mutations (Fin-major and Fin-minor), which both lead to a truncated protein and total absence of nephrin in kidney glomerulus (19). In electron microscopy, these kidneys also lack the filamentous image of slit diaphragm, supporting the central role of nephrin in the architecture of the slit diaphragm (19).

The expression of nephrin was at first thought to be limited to kidney (1). However, in rodents, activity of nephrin gene promoter was observed in some parts of the CNS, such as the ventricular zone of the fourth ventricle; the developing spinal cord, cerebellum, hippocampus, and olfactory bulb; and $\beta$ cells of the pancreas $(20,21)$. In addition, the expression of nephrin in murine testis, spleen, and thymus has been suggested (22). In humans, nephrin has been located in pancreatic $\beta$ cells but not in the CNS (23). We studied the expression of nephrin in 
human and porcine tissues using immunohistochemical, in situ hybridization, and Western blotting techniques and analyzed the clinical data of patients with NPHS1.

\section{METHODS}

Tissue samples. Human fetal samples were collected at autopsy from fetuses at 14,18 , and $20 \mathrm{wk}$ of gestation obtained through prostaglandin-induced abortions as a result of trisomy 21 (Department of Obstetrics and Gynecology, University of Helsinki). In this disorder, abnormalities have not been detected in chromosome 19, where the gene for nephrin is located. Tissue samples were also obtained at autopsies of a newborn (died in sepsis) and five infants. Two human testis samples came from orchiectomies of adult men (supplied by Dr. Leo Dunkel) and one testis sample from a preterm baby (24 wk of gestation) who died of lung problems at the age of $2 \mathrm{wk}$. Two of the infants had NPHS1 (Fin-major/Fin-minor genotypes) and had died after renal transplantation at the ages of 2 and $3 \mathrm{y}$. Three infants died of congenital heart failure at the ages of $4 \mathrm{mo}, 6 \mathrm{mo}$, and $3 \mathrm{y}$. Porcine fetal samples were obtained from aborted pregnancies at days 55 and 80 of gestation (the total length of gestation is $114 \mathrm{~d}$ ). In addition, samples from newborn and a 6-mo-old pigs were used.

The use of the tissue samples and the study protocol were approved by the ethical committees of the Department of Obstetrics and Gynecology and the Hospital for Children and Adolescents of the University of Helsinki. All human studies were conducted with informed consent.

Immunofluorescence staining. Rabbit polyclonal antiserum directed against the intracellular part of nephrin molecule was used for the immunohistochemistry of nephrin. This antiserum was prepared as described previously (24). It was completely specific for nephrin and did not give any immunofluorescence (IF) staining for nonglomerular structures even in low dilutions. One polyclonal antiserum and three MAb preparations against the extracellular domains of nephrin $(3,24)$ were also tested but not used in the IF. These gave a slight background staining on nonglomerular epithelial structures, suggesting cross-reactivity with epitopes in other proteins. Polyclonal guinea pig anti-insulin antiserum (A0564; Dako Corporation, Carpinteria, CA, U.S.A.) was used as a positive control in immunohistochemistry of human and porcine pancreas.

For the IF stainings, cryosections $(5 \mu \mathrm{m})$ of the tissue samples were fixed with $3.5 \%$ paraformaldehyde and incubated overnight at $4^{\circ} \mathrm{C}$ with antibodies diluted in PBS. FITCconjugated secondary antibodies (Jackson ImmunoResearch Laboratories, West Grove, PA, U.S.A.) were incubated for $1 \mathrm{~h}$. Each incubation was followed by three 5-min washes with PBS. Stained sections were mounted in Mowiol (Calbiochem, La Jolla, CA, U.S.A.). Sections used for control were incubated in PBS instead of a primary antibody. Hematoxylin-eosin staining was done parallel with IF to consecutive sections to ensure that the sections contained a representative area of the tissue in question. The sections were examined with a standard Leica DM RX light microscope.

Western blot analysis. Tissue samples were homogenized with Ultra-Turrax (Rose Scientific Ltd., Alberta, Canada) in
Laemmli sample buffer, and the proteins were separated on a gel $(7 \%)$ and blotted onto an Immobilon-P polyvinylidene fluoride membrane (Millipore, Bedford, MA, U.S.A.). After blocking with 5\% nonfat dry milk in PBS, the membrane was stained with rabbit anti-nephrin antibodies followed by peroxidase-conjugated goat anti-rabbit IgG antibodies (Jackson ImmunoResearch). Bound antibodies were visualized using enhanced chemiluminescence (Amersham Biosciences, Uppsala, Sweden). The same antibody preparation was used for Western blotting and IF.

In situ Hybridization. Formalin-fixed, paraffin-embedded sections $(10 \mu \mathrm{m})$ were deparaffinized in xylene, rehydrated in decreasing alcohol series, and treated with proteinase-K (Sigma Chemical Co., St. Louis, MO, U.S.A.) before hybridization. Thereafter, the sections were subjected to in situ hybridization as described previously (25), with some modifications. Briefly, the tissue sections were washed in PBS, acetylated and dehydrated, and then incubated with $1.2 \times 10^{6}$ ${ }^{33}$ P-labeled (1000 Ci/mmol; Amersham, Arlington Heights, IL, U.S.A.) antisense and sense riboprobes in a total volume of 80 $\mu \mathrm{L}$ at $60^{\circ} \mathrm{C}$ for $18 \mathrm{~h}$. After washes with standard saline culture, RNA digestion, and dehydration, the sections were dipped in NTB2 nuclear emulsion (Kodak, Rochester, NY, U.S.A.) and exposed in the dark at $4^{\circ} \mathrm{C}$ for 1 or $2 \mathrm{wk}$. After developing, the sections were counterstained with hematoxylin and eosin. Microscopy was carried out with a standard Leica DM RX light microscope.

The probes for in situ studies were synthesized by subcloning a 287-bp cDNA fragment corresponding to exon 10 in human NPHS1 into pBluescript (Stratagene, La Jolla, CA, U.S.A.), and antisense and sense RNA were produced using T3 and T7 RNA polymerase, respectively.

Clinical data on NPHS1 children. Totally 56 children with NPHS1 have received kidney transplants since 1987 in Finland. The clinical records of these children were analyzed retrospectively, and the data regarding the neurologic findings and pancreatic function were recorded. For studying the function of pancreatic $\beta$ cells, an oral glucose tolerance test was performed on 36 NPHS1 patients and 25 other kidney transplant patients 1 to $5 \mathrm{y}$ after renal transplantation. The test was done according to standard protocols, and blood glucose and serum insulin levels were recorded for $2 \mathrm{~h}$ at 30-min intervals.

For elucidating the testicular function, serum sex hormone levels were measured from eight 15 - to 17 -y-old boys who had NPHS1 and had received a kidney transplant in infancy. Control group consisted of 10 age-matched boys who had received kidney transplants for other reasons. All patients were treated in our hospital and were given the same immunosuppressive medication (cyclosporin A, methylprednisolone, and azathioprine). Before analysis, the serum samples of NPHS1 patients and control subjects were stored at $-20^{\circ} \mathrm{C}$. FSH, LH, testosterone, and inhibin B levels were measured by RIA or ELISA method (26). The pubertal developmental stage was physically examined at the time the serum sample was taken and was recorded according to Tanner (27). 


\section{RESULTS}

Nephrin in normal tissues. The polyclonal antiserum raised against the intracellular part of human nephrin gave a bright linear IF staining in human kidney glomerulus as shown in Figure $1 A$. These antibodies also reacted strongly with porcine nephrin and gave similar staining pattern in pig kidney samples
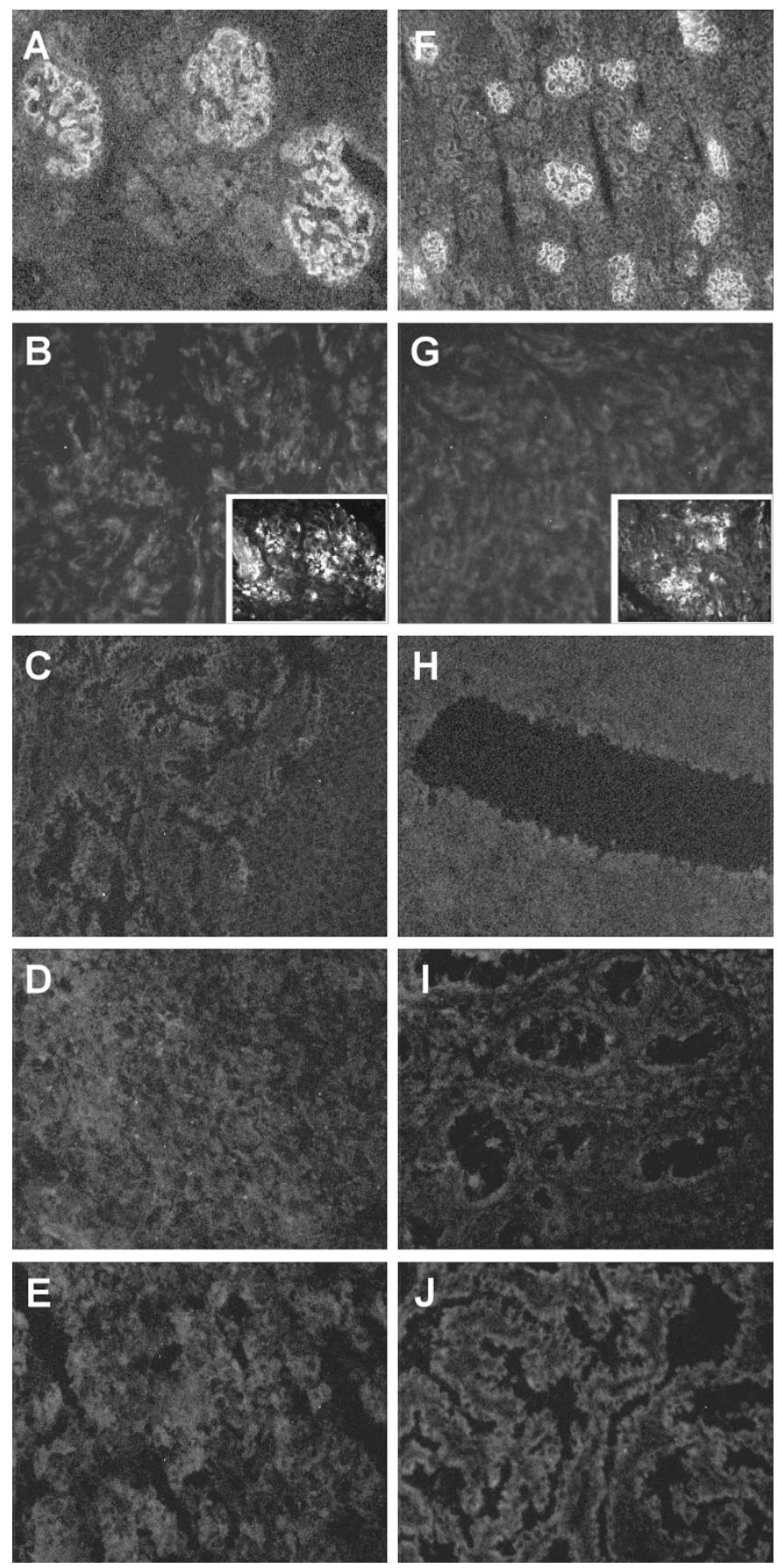

Figure 1. Immunohistochemical staining for nephrin on human $(A-E)$ and porcine $(F-J)$ tissues. A strong positive staining is observed in normal glomeruli: kidney of human fetus (14 wk $A$ ) and kidney of a newborn swine $(F)$. All human extrarenal tissues examined were negative: pancreas $(B)$, cerebellum $(C)$, spinal cord $(D)$, and liver $(E)$. Accordingly, no staining was seen in swine extrarenal tissues: pancreas $(G)$, roof of the fourth ventricle $(H)$, testis $(I)$, and choroid plexus $(J)$. The inserts in $B$ and $G$ represent consecutive sections stained for insulin.
(Fig. $1 F$ ). In contrast to this, no immunoreactivity was seen in 31 tissues samples from nonrenal organs obtained from fetal, newborn, or infant period as summarized in Table 1 and Fig. 1B-E, G-J. Similarly, Western blot analysis of 30 nonrenal tissue samples was negative for nephrin protein (Table 1, Fig. 2).

In situ hybridization for nephrin mRNA was performed on human tissue samples using a probe detecting the extracellular part of nephrin. An intense signal was seen in kidney glomerulus but not in the other 21 tissue samples studied (Table 1, Fig. 3).

Findings in NPHS1 patients. NPHS1 children with Finmajor and Fin-minor mutations do not express nephrin in kidney glomerulus (16), but in situ hybridization for nephrin mRNA gives normal signal (Fig. 4). On this basis, in situ hybridization was performed on tissue samples obtained from autopsies of two NPHS1 children. Samples from pancreas, cerebral cortex, cerebellum, liver, spleen, thyroid gland, lung, heart, liver, and adrenal gland were available and remained negative for nephrin mRNA (Fig. 4).

Clinical records on 56 NPHS1 children with a kidney transplant were analyzed, and the data on neurologic findings and testicular and pancreatic function were recorded. Four $(8 \%)$ of the children had dyskinetic cerebral palsy disorder with dystonic features and athetosis. The symptoms had started in the neonatal period and remained after the kidney transplantation. The great majority of the children $(92 \%)$ did not have problems in motor or sensory function.

No NPHS1 children had developed diabetes before or after kidney transplantation. Oral glucose tolerance test was performed on 36 NPHS1 patients 1-5 y after kidney transplantation. No difference in the serum insulin or glucose levels was observed in NPHS1 patients compared with children who had received kidney transplants for other reasons (Fig. 5).

The pubertal development and testicular function were evaluated in eight male NPHS1 adolescents (Table 2). Six of the eight boys had normal physical gonadal findings as well as normal levels of serum LH, FSH, testosterone, and inhibin B. Two boys had low levels of inhibin B, suggesting impaired Sertoli cell function. One had an increased FSH and a decreased inhibin B level with a small right testis. The other had a decreased level of inhibin B and markedly increased LH and FSH levels.

\section{DISCUSSION}

Nephrin is a podocyte protein that has a crucial role in ultrafiltration of plasma in kidney glomerulus $(2,28)$. Mutations in the nephrin gene lead to congenital nephrotic syndrome, and the protein may also play a role in acquired kidney diseases $(29,30)$. Thus, understanding the biology of nephrin seems important for pediatric nephrology. In this work, we studied the tissue expression of nephrin in human and pig using immunohistochemistry and in situ hybridization. In contrast to the findings in rodents, no nephrin could be detected outside kidney glomerulus by these methods.

Nephrin expression has previously been reported in CNS, pancreas, and some other tissues in mice $(20,21,31)$ as well as 
Table 1. IF staining, Western blotting and in situ hybridization for nephrin in human and swine tissues

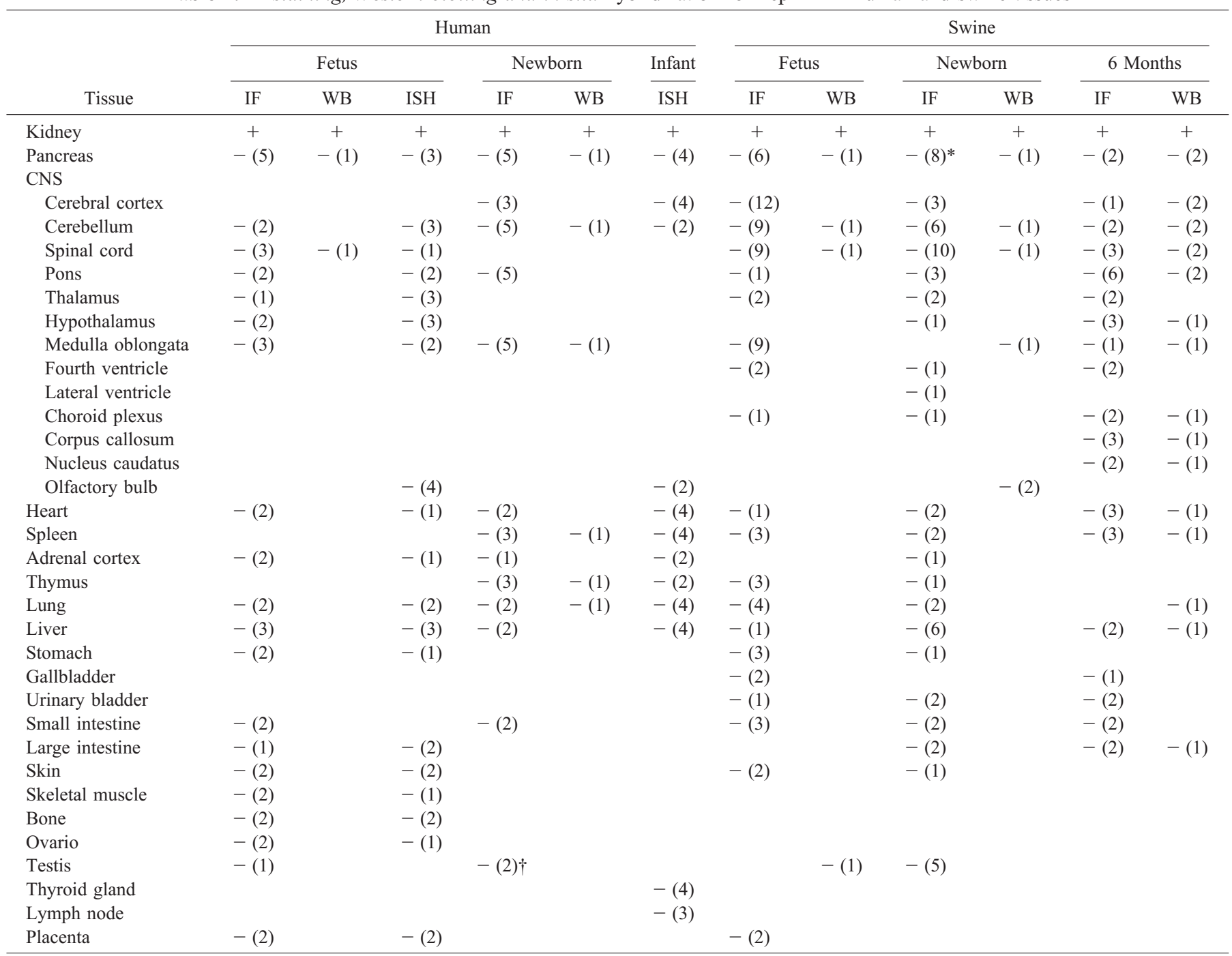

+, positive for nephrin; -, negative for nephrin; ISH, in situ hybridization; WB, Western blotting.

* The caput, corpus, and cauda were examined.

$\dagger$ Adult testis samples from orchiectomies.

in pancreas in human (23). Putaala et al. (21) studied this expression by setting a bacterial lacZ gene as a reporter for the murine NPHS1 promoter (32). In addition to glomerular podocytes, the reporter gene was present in the brain and pancreas of nephrin-deficient mice. In CNS, the gene was localized to the ventricular zone of the fourth ventricle and the developing spinal cord, cerebellum, hippocampus, and olfactory bulb. In the cerebellum, the expression was seen in radial glial cells. With a similar method, Moeller et al. (31) could detect murine NPHS1 promoter activity at the murine medulla oblongata and cerebellum. The expression of nephrin mRNA in various tissues of mice has also been investigated by the reverse transcriptase-PCR (RT-PCR) method, and a high level of nephrin mRNA could be detected in the testes of 1- to 6-wk-old mice. In situ hybridization revealed the expression of the nephrin gene in the Sertoli cells. In addition, immunofluorescent staining studies showed that nephrin was colocalized with anchoring protein $\mathrm{ZO}-1$ in the mouse testis (22). In an RNA dot blot analysis of human tissues, nephrin mRNA was detected in kidney and pancreas but not in CNS. This finding was sup- ported by the results from RT-PCR and immunohistochemical studies, and the precise location of the expression was the $\beta$ cells at the islets of Langerhans (23).

Previously, no systematic analysis of the tissue expression of nephrin protein has been performed. An important issue in this type of study is the specificity of the detection method. We chose immunofluorescence staining of the frozen tissue samples because the antigenicity of the protein in IF is well preserved. Also, the problem with the background staining is small compared with the immunoperoxidase staining. The rabbit polyclonal antibody directed against the intracellular part of nephrin was selected among various antibodies for the stainings $(19,24,33,34)$. Mouse MAb and rabbit polyclonal antiserum directed against the extracellular domains of nephrin were excluded because of their inconsistent staining properties. The extracellular Ig domains may share epitopes with other members of the Ig superfamily and cause cross-reactivity (35). The intracellular part of nephrin has no homology with other known proteins, which may explain the specificity of the antibody preparation used in the study. 

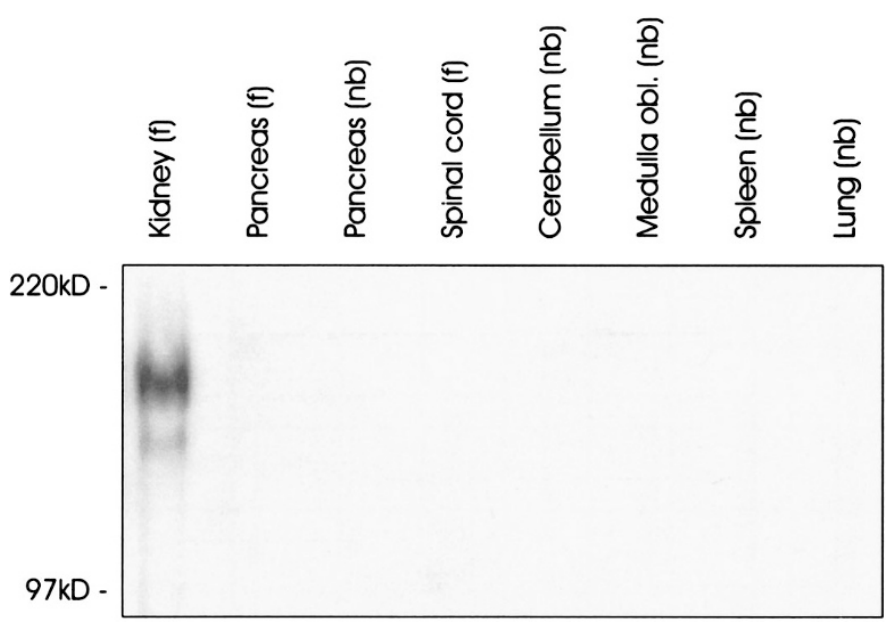

Figure 2. Western immunoblotting for nephrin on tissues of fetal and newborn human. The only band comes from kidney extract used as a positive control.
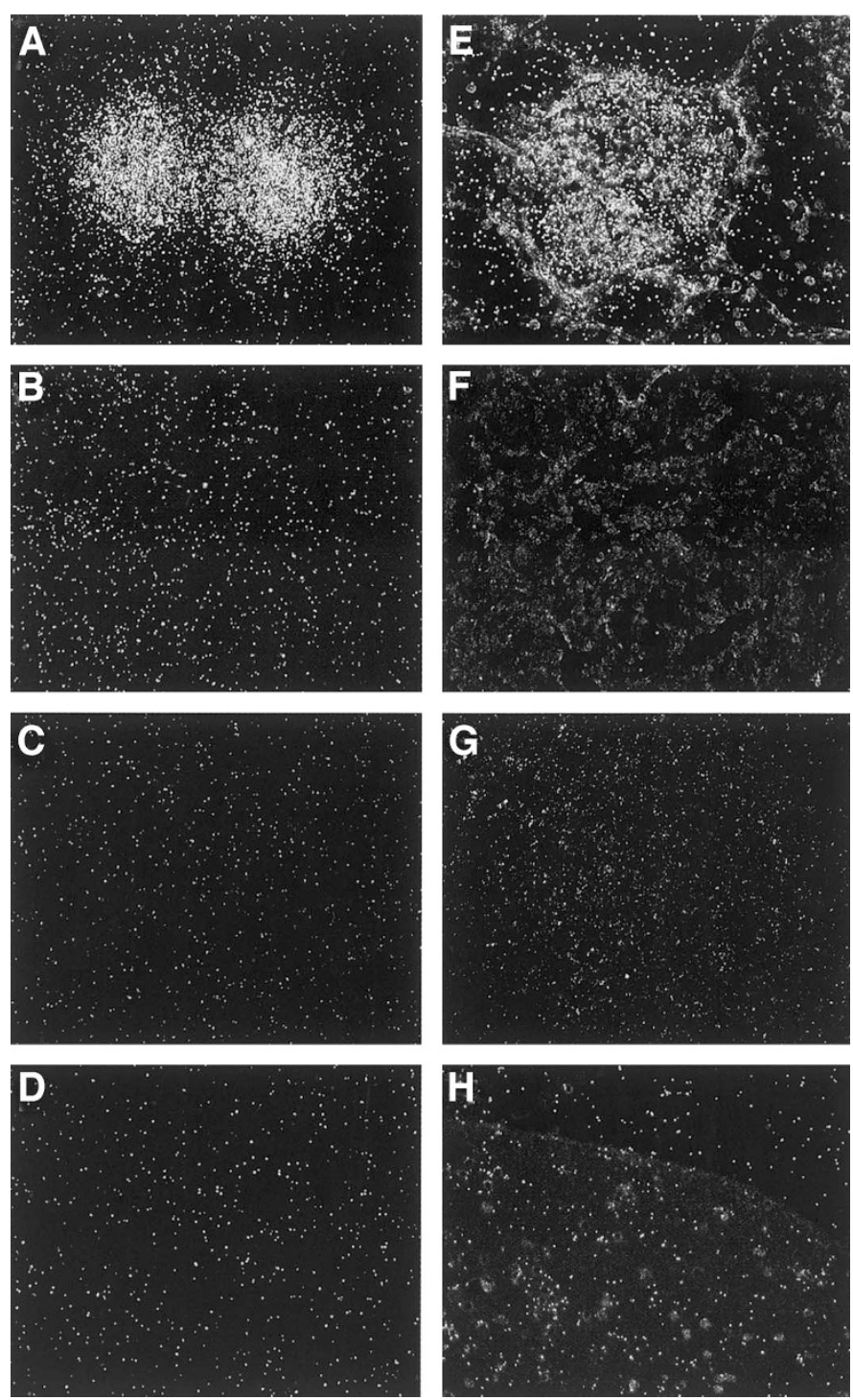

Figure 3. In situ hybridization for nephrin on tissue sections of human fetus $(A-D)$ and infant $(E-H)$. An intense signal is seen in kidney $(A$ and $E)$, but no signal above background is found in pancreas $(B, F)$, cerebellum $(C)$, thalamus $(D)$, spleen $(G)$, and cerebral cortex $(H) . E$ is a larger magnification of a glomerulus.
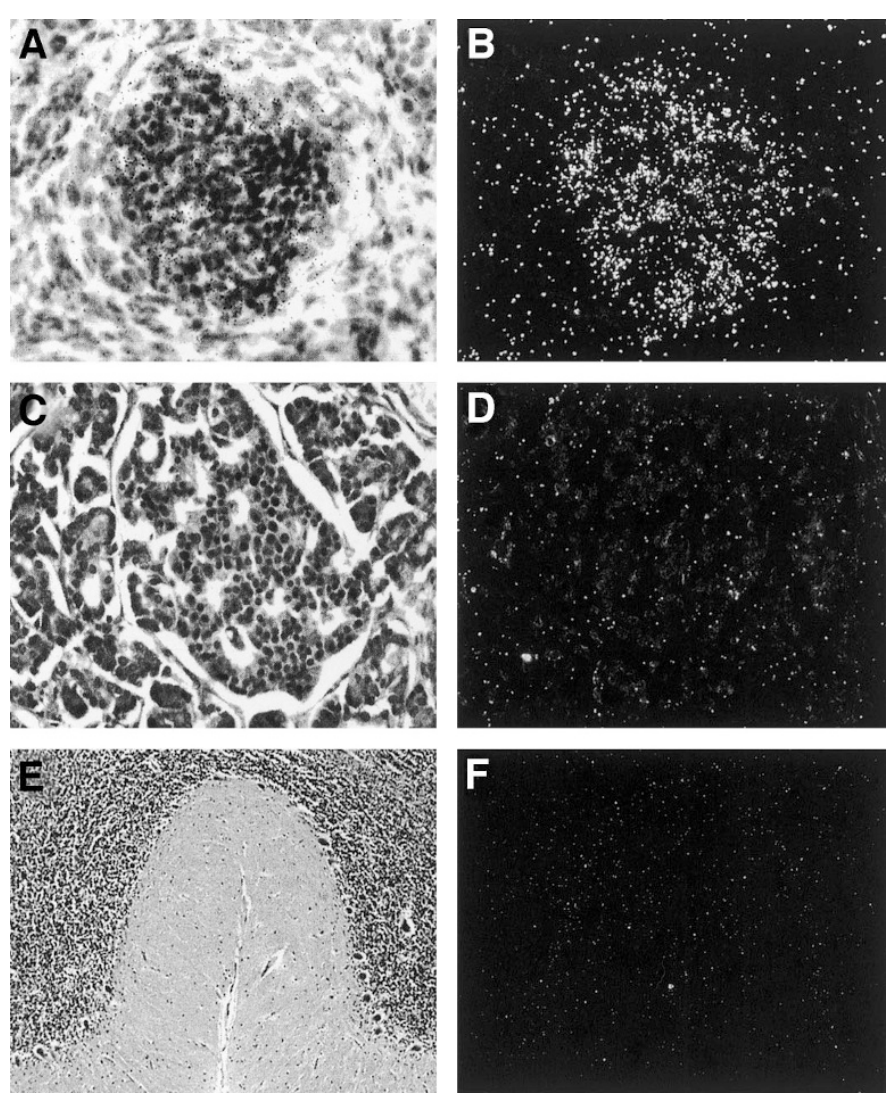

Figure 4. Bright and dark field views of in situ hybridization on tissues of NPHS1 patients. High content of nephrin mRNA is obvious in kidney glomerulus $(A$ and $B)$. The islet of Langerhans $(C$ and $D)$ and the cells of cerebellar cortex $(E$ and $F)$ do not express noticeable amounts of nephrin mRNA.

In addition to the specificity, the sensitivity of the detection system is important in the tissue expression studies. The detection level of the IF method is limited because of the low number of fluorochromes that can be conjugated to one staining antibody. Studies on the lymphocyte receptors have shown that, although several hundred to thousand antigens per cell are required for the visualization, functionally important molecules can be expressed at lower copy numbers (36). Thus, it is clear that the presence of small amounts of nephrin in nonrenal tissues cannot be excluded by the IF method. However, it seems unlikely that nephrin would have a similar crucial role in cell-cell interactions as we see in kidney glomerulus, where the clustering of nephrin on the podocyte surface gives a bright signal in IF.

The lack of nephrin expression in nonrenal tissues was supported by the in situ hybridization for nephrin mRNA. The probe used in these experiments gave intense and specific signal for kidney glomerulus in our earlier studies $(19,24,33$, 34). It corresponds to exon 10 in human NPHS1 gene, which encodes for the fourth extracellular Ig domain of nephrin. In some previous studies, the presence nephrin mRNA in tissue samples was studied by the RT-PCR assay $(22,23)$, which clearly is a more sensitive method than in situ hybridization. However, it may easily give false-positive results. We analyzed fresh tissue samples from two newborn pigs with RT-PCR and obtained positive bands also in extrarenal tissue. The results, 

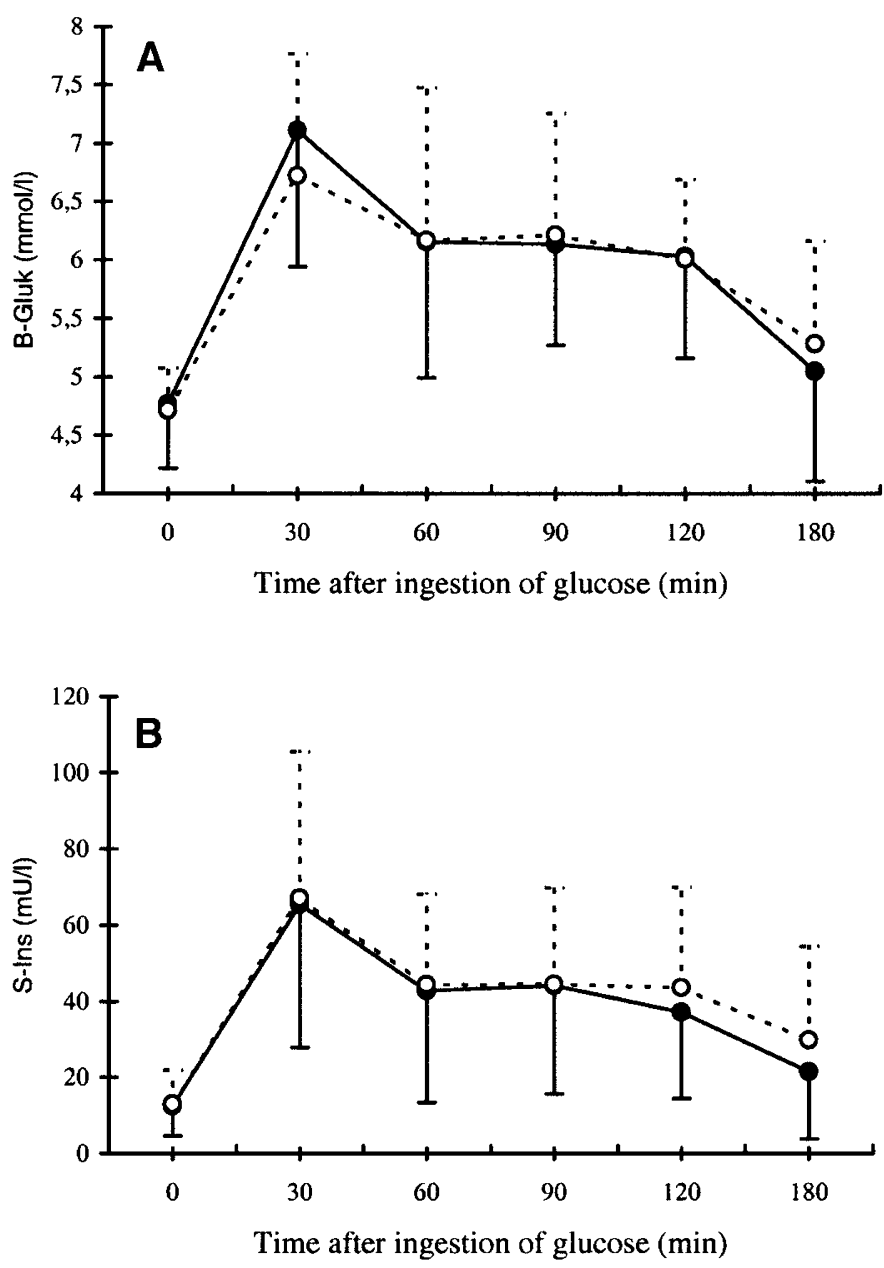

Figure 5. Oral glucose tolerance test in patients with NPHS1. Mean values of blood glucose $(A)$ and serum insulin $(B)$ levels in NPHS1 $(\bullet)$ patients are practically identical to the values of control subjects $(\bigcirc)$. The difference is not statistically significant at any time point $(p>0.05$ by unpaired $t$ test).

however, were inconsistent in repeated experiments, and firm conclusions could not be made.

Another way to acquire information about the expression of nephrin mRNA is to search nephrin expressed sequence tags (ESTs) from databases. Nephrin ESTs were found from six tissues or cell lines: endometrial adenocarcinoma cell line of human uterus, normalized library of human islets of Langerhans, human Wilms' tumor, and human lung carcinoma, as well as mouse kidney and "whole joints" of mouse. It is interesting that there was a hit from human pancreas but no hits from human kidney or mouse tissues that are known to express nephrin, such as the CNS. It is also noteworthy that there was only one hit (from one library) per each tissue. On the other hand, a normalized library does not reflect transcript levels in a tissue. Drawing conclusions from the search results therefore is difficult. On the basis of our results and the data on nephrin ESTs, the presence of small amounts of nephrin mRNA in nonrenal tissues cannot be excluded or confirmed. However, a poor correlation between the cellular level of mRNA and its protein product is a known phenomenon, and from the biologic point of view, the expression of nephrin protein is the major issue.
The possible expression of nephrin in the CNS and pancreas is interesting in biologic and clinical respect. Clinical syndromes that affect both kidney and brain are not rare in pediatric nephrology. Conversely, the expression of nephrin on the surface of pancreatic $\beta$ cell and podocyte slit diaphragm might suggest some role for this protein in the pathogenesis of diabetic nephropathy (23). The biologic relevance of protein expression is often shown in knock-out mice. In the case of nephrin, this is hampered by the fact that nephrin-deficient mice die within $24 \mathrm{~h}$ after birth (21). Instead, human NPHS1 patients receive kidney transplantation and the nonrenal features can easily be evaluated. Finnish patients are especially suitable for this because only two mutations (Fin-major and Fin-minor) account for the disorder in this population. Both mutations lead to a truncated protein, which is not expressed in the kidney glomerulus (19).

Our previous evaluation of nephrotic infants with NPHS1 did not reveal major nonrenal manifestations (19). In this work, we further analyzed the pancreatic and testicular functions as well as neurologic findings in NPHS1 children who had received a kidney transplant. The children responded normally in the glucose tolerance test and did not show tendency for hyperglycemia, although diabetogenic drugs, such as cyclosporin A and tacrolimus, were used after kidney transplantation. Thus, the synthesis of insulin by the pancreatic $\beta$ cells seemed normal in the children. Also, the great majority of the children were neurologically normal. Four of the 56 children, however, had dyskinetic cerebral palsy with severe muscular hypotonia and vigorous dystonic and athetoid movements, which would fit to impaired function in basal ganglia. The reason for this neurologic defect is still unclear, but it is possible that these patients have another inherited disorder with a low penetrance. The clinical signs show resemblance to mitochondrial diseases, and the analysis of mitochondrial genes in these children is in progress. None of the children had clinical symptoms that would indicate pathologic lesions in cerebellum, spinal cord, olfactory bulb, or the hippocampal area. These regions have previously been reported to express the nephrin gene in mice $(20,21)$. In a recent study by Beltcheva et al. (37), nephrin was also expressed diffusely in the murine cerebral cortex and choroid plexus. Some NPHS1 patients who received a transplant in infancy have abnormal electroencephalograms and problems in cognitive performance at school age. These, however, are associated with the pretransplantation complications, such as hypertensive crises, seizures, and cerebral infarcts (38). Approximately $80 \%$ of NPHS1 children attend normal school. Similarly, NPHS1 patients do not have permanent problems (overproduction) in the circulation of the cerebrospinal fluid as determined clinically or by magnetic resonance imaging of the brain (38).

Liu et al. (22) previously detected nephrin in murine Sertoli cells and suggested that the protein might be an important component of the barrier system in testes. This finding has not been repeated in mice or humans. So far, we do not have information on the fertility in NPHS1 because the oldest Finnish patients are in puberty. Clinically, the pubertal development of male and female NPHS1 adolescents seems normal. In this work, we found normal testicular function in six of the 
Table 2. Pubertal stage and serum hormone levels in eight male adolescents with NPHSI

\begin{tabular}{|c|c|c|c|c|c|c|}
\hline & $\begin{array}{c}\text { Age } \\
\text { (years) }\end{array}$ & $\begin{array}{l}\text { Pubertal } \\
\text { stage }\end{array}$ & $\begin{array}{c}\text { LH } \\
(1-9 \mathrm{IU} / \mathrm{L})\end{array}$ & $\begin{array}{c}\text { FSH } \\
(1-7 \mathrm{IU} / \mathrm{L})\end{array}$ & $\begin{array}{c}\text { Testosterone } \\
(10-38 \mathrm{nmol} / \mathrm{L})\end{array}$ & $\begin{array}{c}\text { Inhibin B } \\
(67-323 \mathrm{ng} / \mathrm{L})\end{array}$ \\
\hline \multicolumn{7}{|l|}{ Patients } \\
\hline 1 & 16.3 & $\mathrm{~V}$ & 14.4 & 1.4 & 23.0 & 263 \\
\hline 3 & 16.3 & IV & 7.8 & 18.5 & 14.5 & 49 \\
\hline 4 & 16.7 & $\mathrm{~V}$ & 6.0 & 2.7 & 16.2 & 223 \\
\hline 5 & 17.3 & $\mathrm{~V}$ & 5.8 & 4.3 & 12.5 & 147 \\
\hline 8 & 16.3 & $\mathrm{~V}$ & 5.8 & 1.5 & 25.3 & 317 \\
\hline Median & 16.3 & $\mathrm{~V}$ & 5.8 & 2.7 & 16.6 & 215 \\
\hline \multicolumn{7}{|c|}{ Controls $(n=10)$} \\
\hline Range & $14.8-18.4$ & III-V & $1.5-6.8$ & $1.2-10$ & $6.8-22.8$ & $125-430$ \\
\hline Median & 15.7 & V & 3.7 & 3.4 & 14.75 & 171.5 \\
\hline
\end{tabular}

Control group consists of 10 male adolescents with a kidney transplant but a diagnosis other than NPHS1. Individual values for patients with NPHS1 are shown.

eight pubertal NPHS1 boys. Inhibin B is of special interest here because a negative feedback regulation between the Sertoli cells and the pituitary is established around midpuberty as inhibin B begins to regulate FSH production $(39,40)$. Moreover, male adults with spermatogenic arrest have lower inhibin B levels than the normal male population (40). Two of the boys had inhibin B levels below the normal range. No specific cause could be identified from patient records to explain this finding. However, the fact that most adolescents with NPHS1 had normal testicular function suggests that the disorder is secondary to the heavy medication and complications rather than caused by nephrin gene mutations.

In conclusion, the findings presented show that nephrin protein or mRNA is not expressed in significant quantities anywhere else but kidney glomerulus in human and pig. The tissue expression studies were supported by the phenotype analysis of NPHS1 patients who do not show major nonrenal signs or symptoms.

\section{REFERENCES}

1. Kestilä M, Lenkkeri U, Männikkö M, Lamerdin J, McCready P, Putaala H, Ruotsalainen V, Morita T, Nissinen M, Herva R, Kashtan CE, Peltonen L, Holmberg C, Olsen A, Tryggvason K 1998 Positionally cloned gene for a novel glomerula protein - nephrin - is mutated in congenital nephrotic syndrome. Mol Cell 1:575-582

2. Khoshnoodi J, Tryggvason K 2001 Unraveling the molecular make-up of the glomerular podocyte slit diaphragm. Exp Nephrol 9:355-359

3. Ruotsalainen V, Ljungberg P, Wartiovaara J, Lenkkeri U, Kestilä M, Jalanko H, Holmberg C, Tryggvason K 1999 Nephrin is specifically located at the slit diaphragm of glomerular podocytes. Proc Natl Acad Sci U S A 96:7962-7967

4. Holzman LB, St. John PL, Kovari IA, Verma R, Holthöfer H, Abrahamson DR 1999 Nephrin localizes to the slit pore of the glomerular epithelial cell. Kidney Int 56:1481-1491

5. Huber TB, Kottgen M, Schilling B, Walz G, Benzing T 2001 Interaction with podocin facilitates nephrin signaling. J Biol Chem 276:41543-41546

6. Schwarz K, Simons M, Reiser J, Saleem MA, Faul C, Kriz W, Shaw AS, Holzman LB, Mundel P 2001 Podocin, a raft-associated component of the glomerular slit diaphragm, interacts with CD2AP and nephrin. J Clin Invest 108:1621-1629

7. Shih NY, Li J, Cotran R, Mundel P, Miner JH, Shaw AS 2001 CD2AP localizes to the slit diaphragm and binds to nephrin via a novel C-terminal domain. Am J Pathol 159:2303-2308

8. Huber TB, Hartleben B, Kim J, Schmidts M, Schermer B, Keil A, Egger L, Lecha RL, Borner C, Pavenstadt H, Shaw AS, Walz G, Benzing T 2003 Nephrin and CD2AP associate with phosphoinositide 3-OH kinase and stimulate AKT-dependent signaling. Mol Cell Biol 23:4917-4928

9. Verma R, Wharram B, Kovari I, Kunkel R, Nihalani D, Wary KK, Wiggins RC, Killen P, Holzman LB 2003 Fyn binds to and phosphorylates the kidney slit diaphragm component Nephrin. J Biol Chem 278:20716-20723

10. Lahdenpera J, Kilpelainen P, Liu XL, Pikkarainen T, Reponen P, Ruotsalainen V, Tryggvason K 2003 Clustering-induced tyrosine phosphorylation of nephrin by Src family kinases. Kidney Int 64:404-413
11. Barletta GM, Kovari IA, Verma RK, Kerjaschki D, Holzman LB 2003 Nephrin and Neph1 co-localize at the podocyte foot process intercellular junction and form cis hetero-oligomers. J Biol Chem 278:19266-19271

12. Gerke P, Huber TB, Sellin L, Benzing T, Walz G 2003 Homodimerization and heterodimerization of the glomerular podocyte proteins nephrin and NEPH1. J Am Soc Nephrol 14:918-926

13. Liu G, Kaw B, Kurfis J, Rahmanuddin S, Kanwar YS, Chugh SS 2003 Neph1 and nephrin interaction in the slit diaphragm is an important determinant of glomerular permeability. J Clin Invest 112:209-221

14. Kestilä M, Männikkö M, Holmberg C, Gyapay G, Weissenbach J, Savolainen ER, Peltonen L, Tryggvason K 1994 Congenital nephrotic syndrome of the Finnish type maps to the long arm of chromosome 19. Am J Hum Genet 54:757-764

15. Holmberg C, Jalanko H, Tryggvason K, Rapola J 1999 Pediatric Nephrology. Lippincott Williams \& Wilkins, Baltimore, pp 765-778

16. Lenkkeri U, Mannikko M, McCready P, Lamerdin J, Gribouval O, Niaudet PM, Antignac CK, Kashtan CE, Holmberg C, Olsen A, Kestilä M, Tryggvason K 1999 Structure of the gene for congenital nephrotic syndrome of the Finnish type (NPHS1) and characterization of mutations. Am J Hum Genet 64:51-61

17. Beltcheva O, Martin P, Lenkkeri U, Tryggvason K 2001 Mutation spectrum in the nephrin gene (NPHS1) in congenital nephrotic syndrome. Hum Mutat 17:368-373

18. Koziell A, Grech V, Hussain S, Lee G, Lenkkeri U, Tryggvason K, Scambler P 2002 Genotype/phenotype correlations of NPHS1 and NPHS2 mutations in nephrotic syndrome advocate a functional inter-relationship in glomerular filtration. Hum Mol Genet 11:379-388

19. Patrakka J, Kestilä M, Wartiovaara J, Ruotsalainen V, Tissari P, Lenkkeri U, Männikkö M, Visapää I, Holmberg C, Rapola J, Tryggvason K, Jalanko H 2000 Congenital nephrotic syndrome (NPHS1): features resulting from different mutations in Finnish patients. Kidney Int 58:972-980

20. Putaala H, Sainio K, Sariola H, Tryggvason K 2000 Primary structure of mouse and rat nephrin cDNA and structure and expression of the mouse gene. J Am Soc Nephrol 11:991-1001

21. Putaala H, Soininen R, Kilpeläinen P, Wartiovaara J, Tryggvason K 2001 The murine nephrin gene is specifically expressed in kidney, brain and pancreas: inactivation of the gene leads to massive proteinuria and neonatal death. Hum Mol Genet 10:1-8

22. Liu L, Aya K, Tanaka H, Shimizu J, Ito S, Seino Y 2001 Nephrin is an important component of the barrier system in the testis. Acta Med Okayama 55:161-165

23. Palmén T, Ahola H, Palgi J, Aaltonen P, Luimula P, Wang S, Jaakkola I, Knip M, Otonkoski T, Holthöfer H 2001 Nephrin is expressed in the pancreatic beta cells. Diabetologia 44:1274-1280

24. Ruotsalainen V, Patrakka J, Tissari P, Reponen P, Hess M, Kestilä M, Holmberg C, Salonen R, Heikinheimo M, Wartiovaara J, Tryggvason K, Jalanko H 2000 Role of nephrin in cell junction formation in human nephrogenesis. Am J Pathol 157:1905-1916

25. Wilkinson DG 1992 In Situ Hybridization: A Practical Approach. IRL Press, Oxford, pp 75-83

26. Andersson AM, Juul A, Petersen JH, Muller J, Groome NP, Skakkebaek NE 1997 Serum inhibin B in healthy pubertal and adolescent boys: relation to age, stage of puberty, and follicle-stimulating hormone, luteinizing hormone, testosterone, and estradiol levels. J Clin Endocrinol Metab 82:3976-3981

27. Tanner JM, Whitehouse RH 1976 Clinical longitudinal standards for height, weight, height velocity, weight velocity, and stages of puberty. Arch Dis Child 1976 51:170-179

28. Jalanko H, Patrakka J, Tryggvason K, Holmberg C 2001 Genetic kidney diseases disclose the pathogenesis of proteinuria. Ann Med 33:526-533

29. Furness PN, Hall LL, Shaw JA, Pringle JH 1999 Glomerular expression of nephrin is decreased in acquired human nephrotic syndrome. Nephrol Dial Transplant 14:12341237

30. Doublier S, Ruotsalainen V, Salvidio G, Lupia E, Biancone L, Conaldi PG, Reponen $\mathrm{P}$, Tryggvason K, Camussi G 2001 Nephrin redistribution on podocytes is a potential mechanism for proteinuria in patients with primary acquired nephrotic syndrome. Am J Pathol 158:1723-1731 
31. Moeller MJ, Kovari IA, Holzman LB 2000 Evaluation of a new tool for exploring podocyte biology: mouse Nphs1 5' flanking region drives LacZ expression in podocytes. J Am Soc Nephrol 11:2306-2314

32. Wong MA, Cui S, Quaggin SE 2000 Identification and characterization of a glomerular-specific promoter from the human nephrin gene. Am J Physiol 279:F1027-F1032

33. Patrakka J, Ruotsalainen V, Ketola I, Holmberg C, Heikinheimo M, Tryggvason K, Jalanko H 2001 Expression of nephrin in pediatric kidney diseases. J Am Soc Nephrol 12:289-296

34. Patrakka J, Ruotsalainen V, Reponen P, Qvist E, Laine J, Holmberg C, Tryggvason $\mathrm{K}$, Jalanko H 2002 Recurrence of nephrotic syndrome in kidney grafts of patients with congenital nephrotic syndrome of the Finnish type: role of nephrin. Transplantation 73:394-403

35. Sun C, Kilburn D, Lukashin A, Crowell T, Gardner H, Brundiers R, Diefenbach B Carulli JP 2003 Kirrel2, a novel immunoglobulin superfamily gene expressed primarily in beta cells of the pancreatic islets. Genomics 82:130-142
36. Scheffold A, Assenmacher M, Reiners-Schramm L, Lauster R, Radbruch A 2000 High-sensitivity immunofluorescence for detection of the pro- and anti-inflammatory cytokines gamma interferon and interleukin-10 on the surface of cytokine-secreting cells. Nat Med 6:107-110

37. Beltcheva O, Kontusaari S, Fetissov S, Putaala H, Kilpelainen P, Hokfelt T, Tryggvason K 2003 Alternatively used promoters and distinct elements direct tissuespecific expression of nephrin. J Am Soc Nephrol 14:352-358

38. Qvist E, Pihko H, Fagerudd P, Valanne L, Lamminranta S, Karikoski J, Sainio K, Rönnholm K, Jalanko H, Holmberg C 2002 Neurodevelopmental outcome in highrisk patients after renal transplantation in early childhood. Pediatr Transplant 6:53-62

39. Bergada I, Bergada C, Campo S 2001 Role of inhibins in childhood and puberty. J Pediatr Endocrinol Metab 14:343-353

40. Andersson AM, Muller J, Skakkebaek NE 1998 Different roles of prepubertal and postpubertal germ cells and Sertoli cells in the regulation of serum inhibin B levels. J Clin Endocrinol Metab 83:4451-4458 